\title{
Foliar application of Burkholderia sp. strain TNAU-1 leads to activation of defense responses in chilli (Capsicum annuum L.)
}

\author{
Srinivasan Madhavan, Vaikuntavasan Paranidharan and Rethinasamy Velazhahan*
}

\begin{abstract}
Department of Plant Pathology, Centre for Plant Protection Studies, Tamil Nadu Agricultural University, Coimbatore641 003, Tamil Nadu, India
\end{abstract}

*Corresponding author: Ph. 091-422-6611226, Fax: 091-422-6611437, velazhahan@hotmail.com

Received: 22 September 2011; Accepted: 27 January 2012

\begin{abstract}
Induction of phenolics, peroxidase (P0), polyphenol oxidase (PP0), chitinase and thaumatin-like proteins (TLP) in leaves of chilli (Capsicum annuum L.) in response to foliar application with a biocontrol agent Burkholderia sp. strain TNAU-1 was studied. Chilli plants, when sprayed with Burkholderia sp. strain TNAU-1 showed increase in phenolic content one day after application and the maximum accumulation was observed seven days after treatment. Three new peroxidase isozymes (P0-1, P0-2 and P0-3) were induced in chilli leaves upon treatment with Burkholderia sp. strain TNAU-1. The activity of all the peroxidases was at the maximum level three days after treatment and subsequently decreased. Protein extracts obtained from Burkholderia sp. strain TNAU-1 treated plants exhibited a major polyphenol oxidase (PPO-1) one day after treatment. The activity of PP0-1 subsequently decreased, but continuously present throughout the experimental period of 15 days. Western blot analysis of protein extracts from Burkholderia $\mathrm{sp}$. strain TNAU- 1 treated chilli leaves revealed that two TLPs with sizes of 23 and $25 \mathrm{kDa}$ and a chitinase with an apparent molecular weight of $28 \mathrm{kDa}$ were induced three days after treatment.
\end{abstract}

Key words: Capsicum annuum, chitinase, induced resistance, peroxidase, phenolics, polyphenol oxidase, thaumatin-like protein

\section{INTRODUCTION}

Chilli (Capsicum annuum L.) is an important crop in many parts of the world. Its production is affected by a number of diseases. Among the most devastating is anthracnose or fruit rot caused by Colletotrichum spp. This disease is prevalent in most chilli-producing areas throughout the world and often results in high yield losses (Than et al., 2008a). Several species of Colletotrichum viz., C. capsici (Butler and Bisby), C. gloeosporioides (Penz.), C. acutatum (Simmonds), C. atramentarium (Berk and Broome), C. dematium (Pers.) and $C$. coccodes (Wallr.), Glomerella cingulata (Stoneman) along with $A$. alternata (Keissler) have been reported as causal agents of chilli fruit rot worldwide (Than et al., 2008b).
Anthracnose is mainly a problem on mature fruits, causing severe losses via both pre and post-harvest fruit decay (Hadden and Black, 1989; Bosland and Votava, 2003). Typical anthracnose symptoms on chilli fruit include sunken necrotic tissues, with concentric rings of acervuli. In some cases, the lesions are brown and then turn black, due to the formation of setae and sclerotia.

Fruit rot reduces dry weight, capsaicin and oleoresin content of affected fruits (Mistry et al., 2008), leading to reduction in the medicinal properties of chilli. Synthetic chemical fungicides are commonly used to control anthracnose. However, this is becoming less acceptable since it increases the potential for build-up of resistance in 
the pathogen to fungicides and also conflicts with the public concern for fungicide residues. The exploitation of induced resistance in plants is a promising environment-friendly strategy for controlling plant diseases. It is well known that plants have several lines of defense against invading pathogens including preformed barriers and induced responses. The latter include rapid generation of reactive oxygen species, synthesis of phytoalexins, onset of hypersensitive cell death and synthesis of pathogenesis-related proteins (Roth et al., 2000; Afroz et al., 2011).

Certain strains of Plant growth- promoting rhizobacteria (PGPR) are capable of stimulating different defense mechanisms that leads to systemic disease protection in plants, which has been termed "induced systemic resistance" (ISR) (Van Loon et al., 1998; Van Loon, 2007) and hence it is possible that even susceptible plants can be protected from diseases by enhancing their own defense mechanisms by application of PGPR. Anand et al. (2007) reported induction of systemic resistance in chilli plants against fruit rot disease by foliar application of Pseudomonas fluorescens isolate Pf1. Recently we observed that foliar application of powder formulation of Burkholderia sp. strain TNAU-1 at $0.2 \%(\mathrm{w} / \mathrm{v})$ concentration at the time of flowering followed by four sprayings at 15 days interval significantly reduced the incidence of chilli anthracnose under field conditions (Madhavan et al., 2011. Unpublished). The results suggest that activation of the host biochemical defense mechanisms may be involved in the suppression of chilli anthracnose disease. In the present study we investigated the induction of defenserelated enzymes viz., peroxidase, polyphenol oxidase and accumulation of phenolics and PR-proteins in leaves of chilli in response to treatment with Burkholderia sp. strain TNAU-1. The involvement of these enzymes in the defense response of chilli plants against $C$. capsici is discussed.

\section{MATERIALS AND METHODS}

Fungal and bacterial cultures: The fungus, Colletotrichum capsici was isolated from chilli fruits showing symptoms of anthracnose disease and maintained on potato dextrose agar (PDA) medium under laboratory conditions (Madhavan et al., 2010). Burkholderia sp. strain TNAU-1 was obtained from the culture collection of the Department of Plant Pathology, Tamil Nadu Agricultural University, Coimbatore, India and used in this study.

Induction of defense mechanisms: Talc-based powder formulation of Burkholderia sp. strain TNAU-1 was developed as described by Vijaysamundeeswari et al. (2010). To study the induction of phenolics, peroxidase, polyphenol oxidase, chitinase and TLP in Burkholderia sp. strain TNAU-1- treated plants, 25-day-old chilli plants (Capsicum annuum L. cv. CO1) were sprayed with powder formulation of Burkholderia sp. strain TNAU-1 (0.2\%) until run-off. Control plants were sprayed with sterile distilled water. At various time intervals the leaf samples were collected and immediately frozen in liquid nitrogen and stored at $-70^{\circ} \mathrm{C}$ until analysis.

Estimation of phenolic content: Chilli leaves (1 g) were ground to a fine powder in liquid nitrogen and extracted in $10 \mathrm{ml}$ of $80 \%$ methanol for $15 \mathrm{~min}$ at $70^{\circ} \mathrm{C}$ (Swain and Hillis, 1959). For estimation of phenolic content, one $\mathrm{ml}$ of the methanolic extract was mixed with 5 $\mathrm{ml}$ of distilled water and $250 \mu \mathrm{l}$ of Folin-Ciocalteau reagent $(1 \mathrm{M})$ and the solution was incubated at $25^{\circ} \mathrm{C}$. After $3 \mathrm{~min} 1 \mathrm{ml}$ of saturated solution of $\mathrm{Na}_{2} \mathrm{CO}_{3}$ and $1 \mathrm{ml}$ of distilled water were added and the reaction mixture was incubated at $25^{\circ} \mathrm{C}$ for $1 \mathrm{~h}$. The absorption of the developed blue colour was measured at $725 \mathrm{~nm}$ using a Beckman DU64 spectrophotometer (Beckman Instruments Inc., California, USA). The content of the total soluble phenols was calculated based on a standard curve obtained from a Folin-Ciocalteau reaction with phenol and expressed as phenol equivalents in $\mu \mathrm{g} \mathrm{g}^{-1}$ fresh mass.

Peroxidase isozyme analysis: Peroxidase isozymes were analyzed as per the procedure described by Eshel et al. (2002). The enzyme extract was prepared by homogenizing one gram of leaf sample in $5 \mathrm{ml}$ of $0.1 \mathrm{M}$ phosphate buffer, pH 7.0 in a chilled pestle and mortar. The homogenate was centrifuged in a refrigerated centrifuge at $12,000 \times g$ at $4^{\circ} \mathrm{C}$ for $20 \mathrm{~min}$ and the supernatant so obtained was used for PO isozyme analysis. The protein concentration in the samples was determined by the method of Bradford with bovine serum albumin as the standard (Bradford, 1976). Samples $(50 \mu \mathrm{g})$ were mixed with sample buffer (150 mM Tris-HCl (pH 6.8), $3 \%$ bromophenol blue and $30 \%$ glycerol) and separated by nondenaturing polyacrylamide gel electrophoresis (PAGE) using a 
$12 \%$ acrylamide gel. Electrophoresis of protein samples was carried out in a Mighty Small II gel electrophoresis unit (Hoefer Scientific Instruments, San Francisco, CA, USA) at a constant current of $20 \mathrm{~mA}$ for $2 \mathrm{~h}$.

After electrophoresis the gel was equilibrated for 30 min in $50 \mathrm{ml}$ of $0.1 \mathrm{M}$ potassium phosphate buffer, pH 7.0. Peroxidase isoforms were then visualized by incubating the gel in the dark with freshly prepared diaminobenzidine solution (10 mg in $20 \mathrm{ml} 0.05 \mathrm{M}$ phosphate buffer, $\mathrm{pH}$ 7.0) for 5-10 min, washing twice with water and then incubating with $10 \mu \mathrm{l}$ $30 \% \mathrm{H}_{2} \mathrm{O}_{2}$ in $20 \mathrm{ml}$ of $0.05 \mathrm{M}$ phosphate buffer, $\mathrm{pH} 7.0$.

Polyphenol oxidase isozyme analysis: The enzyme extract prepared for peroxidase isozyme analysis was used in polyphenol oxidase isozyme analysis. Separation of proteins $(50 \mu \mathrm{g})$ was achieved by non-denaturing polyacrylamide gel electrophoresis (PAGE) of samples using a $12 \%$ acrylamide gel as described above. Following electrophoresis, the gel was equilibrated for $30 \mathrm{~min}$ in $50 \mathrm{ml}$ of $0.1 \mathrm{M}$ potassium phosphate buffer, $\mathrm{pH} 7.0$. Polyphenol oxidase isoforms were then visualized by incubating the gel in the dark with freshly prepared $p$-phenylene diamine solution (10 mg in $20 \mathrm{ml} 0.1 \mathrm{M}$ phosphate buffer, $\mathrm{pH} 7.0$ ) for 5-10 min, washing twice with water and then incubating with $0.2 \mathrm{M}$ catechol in the same buffer. The addition of catechol was followed by a gentle shaking which resulted in appearance of dark brown discrete protein bands (Jayaraman et al., 1987).

Immunoblot analysis: Leaf samples (1g) were homogenized in liquid nitrogen and extracted in $5 \mathrm{ml}$ of $0.1 \mathrm{M}$ phosphate buffer, $\mathrm{pH} 6.5$, containing $0.5 \mathrm{mM}$ phenylmethylsulfonyl fluoride (Velazhahan et al., 1998). The homogenate was centrifuged at $4^{\circ} \mathrm{C}$ for $15 \mathrm{~min}$ at $12,000 \times g$ and the supernatant was collected. The protein concentration in the samples was determined by the method of Bradford with bovine serum albumin as the standard (Bradford, 1976). For immunoblot analysis, 100 $\mu \mathrm{g}$ of proteins were separated by sodium dodecylsulphatepolyacrylamide gel electrophoresis (SDS-PAGE) in a Mighty Small II gel electrophoresis unit (Hoefer Scientific Instruments, San Francisco, CA, USA) with 12\% acrylamide resolving gel and $4 \%$ acrylamide stacking gel according to the method of Laemmli (1970). A constant current of 20 $\mathrm{mA}$ per gel $(0.75 \mathrm{~mm} \times 8 \mathrm{~cm} \times 7 \mathrm{~cm})$ was applied. After electrophoresis, the proteins were electroblotted onto a polyvinylene difluoride (PVDF) membranes (Immobilon-P membrane; Millipore, Bedford, MA) for 30 min at $140 \mathrm{~mA}$ in a Bio-Rad semi-dry transblot apparatus (Bio-Rad, Hercules, CA, USA) using $48 \mathrm{mM}$ Tris buffer, pH 9.2, containing $39 \mathrm{mM}$ glycine, $1.3 \mathrm{mM} \mathrm{SDS}$ and $20 \%(\mathrm{v} / \mathrm{v})$ methanol in accordance with the manufacturer's instructions. The membrane was blocked for $3 \mathrm{~h}$ at room temperature $\left(28 \pm 2^{\circ} \mathrm{C}\right)$ in $3.0 \%$ $(\mathrm{w} / \mathrm{v})$ bovine serum albumin in Tris-buffered saline $(10 \mathrm{mM}$ Tris- $\mathrm{HCl}, \mathrm{pH}$ 7.9, $140 \mathrm{mM} \mathrm{NaCl}$ ) (TBS) containing 0.05\% (v/v) Tween-20 (TBST). After blocking, immunoblots were washed three times for 5 min each with TBST and incubated for overnight in TBST containing specific primary antibody for chitinase and TLP at 1:1000 dilution. Antiserum raised against a barley chitinase/ grapes TLP (a gift of Dr. S.Muthukrishnan, Kansas State University, Manhattan, Kansas, USA) was used as primary antibody for chitinase and TLP respectively. The membranes were washed five times with TBST for $5 \mathrm{~min}$. It was then incubated in TBST containing horseradish peroxidase (HRP) -conjugated goat anti-rabbit IgG (Bio-Rad, Hercules, CA, USA) at a 1:1,000 dilution for $3 \mathrm{~h}$, washed thrice for 5 min each with TBST and twice with TBS. Binding of the secondary antibody was detected by reaction of the antibody-HRP-conjugate with freshly prepared substrate solution consisting of $15 \mu \mathrm{l}$ of $30 \% \mathrm{H}_{2} \mathrm{O}_{2}, 5 \mathrm{ml}$ of $0.3 \%$ (w/v) 4-chloro-1-naphthol (BioRad, Hercules, CA, USA) in methanol, and $25 \mathrm{ml}$ of TBS for 3-5 min. Presence of TLP and chitinase were detected by observing the development of bands in the membrane. Apparent molecular masses of proteins were determined by comparison with molecular weight standards (Rainbow marker, RPN 756, Amersham Pharmacia, NJ, USA).

\section{RESULTS}

Phenolic content: Chilli leaves when sprayed with the powder formulation of Burkholderia sp. strain TNAU1 showed dramatic increase in phenolic content one day after treatment and the maximum accumulation of phenols was observed seven days after treatment (Figure 1). The phenolic content subsequently declined but remained significantly at higher levels when compared with control at all sampling stages. 


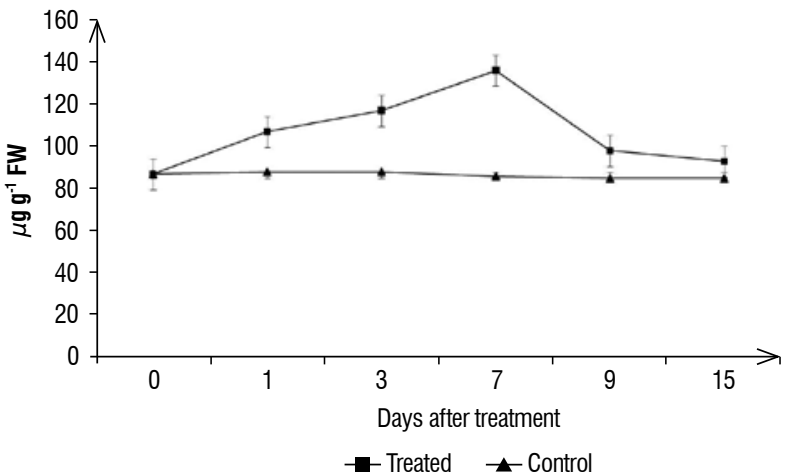

Figure 1. Time course increase in phenolic content in chilli leaves in response to treatment with Burkholderia sp. strain TNAU-1. Phenolic content in control and treated chilli plants was determined colorimetrically. Bars represent standard deviations of the means.

Peroxidase isozyme profile: Three new peroxidase isozymes (P0-1, P0-2 and P0-3) were induced in chilli leaves upon treatment with Burkholderia sp. strain TNAU-1 (Figure 2). P0-1 appeared one day after treatment and the intensity of the protein reached the maximum level three days after treatment. In addition, induction of two more PO isoforms (P0-2 and P0-3) could be detected three days after treatment with Burkholderia sp. strain TNAU-1. The activity of all the peroxidases was at the maximum level three days after treatment and subsequently decreased. The activity of PO was very low or at undetectable level in control leaves.

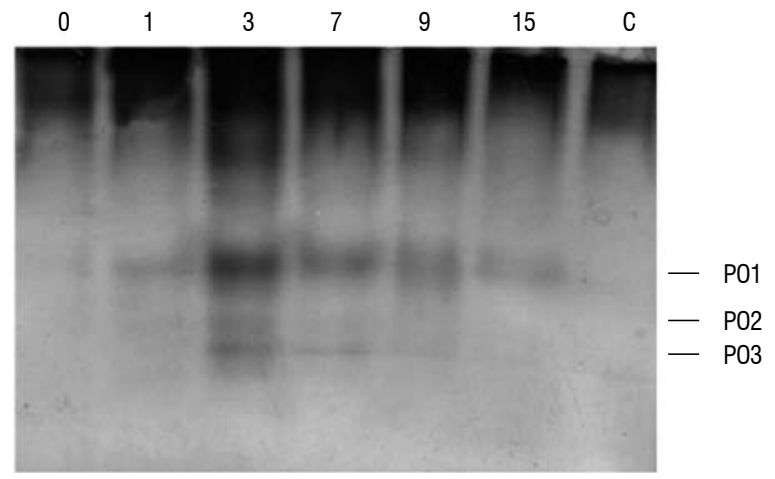

Figure 2. Peroxidase isoenzymes in protein extracts from chilli leaves treated with Burkholderia sp. strain TNAU-1. Fifty micrograms equivalent of protein was loaded on each lane in a $12 \%$ non-denaturing gel. Following electrophoresis, the gel was incubated for 30 min with $0.1 \mathrm{M}$ potassium phosphate buffer, $\mathrm{pH} 7.0$, and peroxidase isoforms were visualized by incubating the gel in the dark with freshly prepared diaminobenzidine solution for 5-10 min, washing twice with water and then incubating with $10 \mu \mathrm{l} 30 \%$ $\mathrm{H}_{2} \mathrm{O}_{2}$ in $20 \mathrm{ml}$ of $0.05 \mathrm{M}$ phosphate buffer, $\mathrm{pH}$ 7.0. The numbers indicate days after treatment. Abbreviation used: C-control.
Polyphenol oxidase isozyme pattern: Protein extracts obtained from Burkholderia sp. strain TNAU-1 treated plants exhibited a major polyphenol oxidase (PPO-1) one day after treatment (Figure 3). The activity of PPO-1 subsequently decreased, but continuously present throughout the experimental period of 15 days. The activity of PPO-1 was very low or at undetectable level in control leaves.

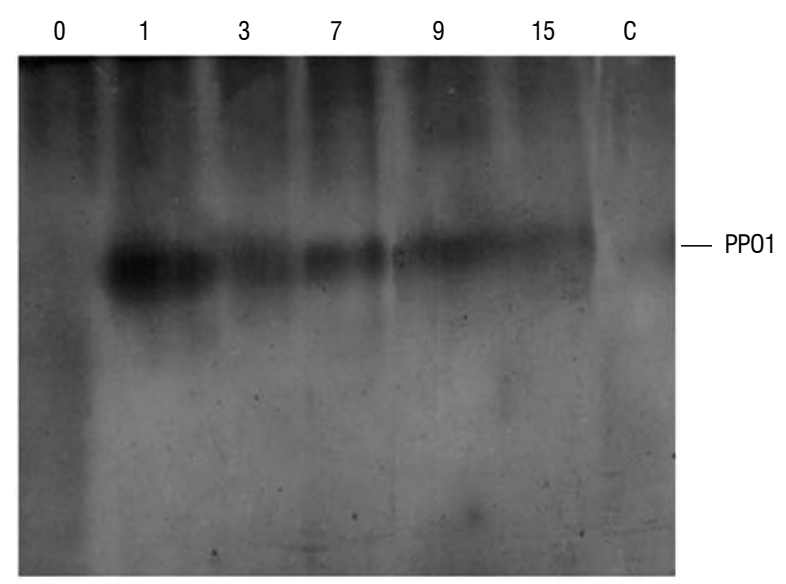

Figure 3. Polyphenol oxidase isoenzymes in protein extracts from chilli leaves treated with Burkholderia sp. strain TNAU-1. Fifty micrograms equivalent of protein was loaded on each lane in a $12 \%$ non-denaturing gel. Following electrophoresis, the gel was incubated for 30 min with $0.1 \mathrm{M}$ potassium

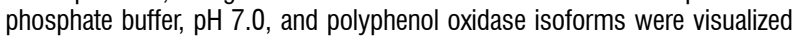
by incubating the gel in the dark with freshly prepared $p$-phenylene diamine solution for 5-10 min, washing twice with water and then incubating with 0.2 $\mathrm{M}$ catechol resulting in appearance of dark brown discrete protein bands. The numbers indicate days after treatment. C- control.

Induction of TLP: Western blot analysis of protein extracts from control and Burkholderia sp. strain TNAU-1 treated chilli leaves revealed that two proteins with sizes of 23 and $25 \mathrm{kDa}$ cross reacting with grapes TLP antibody were induced three days after treatment (Figure 4). The levels of both the proteins were at the maximum at three days after treatment, slightly decreased seven days after treatment and came to basal level thereafter. No PR-5 proteins could be detected in the control plants. 


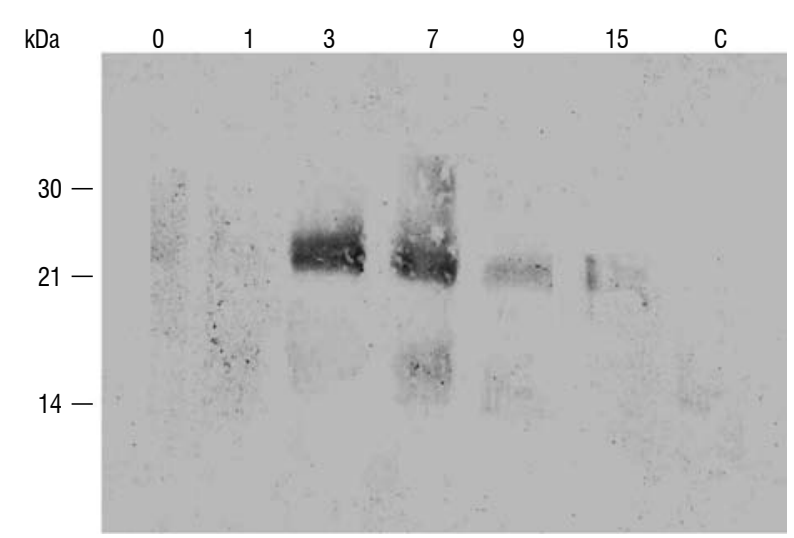

Figure 4. Induction of PR-5 proteins in chilli leaves in response to treatment with Burkholderia sp. strain TNAU-1. Aliquots of total proteins $(100 \mu \mathrm{g})$ extracted from control (lane C) and Burkholderia sp. strain TNAU-1 treated chilli leaves were analyzed by Western blotting after SDS-PAGE using grapes TLP antiserum. The numbers indicate days after treatment. Molecular weight markers are shown on the left.

Induction of chitinase: Immunoblot analysis of protein extracts from control plants revealed that the barley chitinase antiserum was able to recognize two proteins with apparent molecular weights of $30 \mathrm{kDa}$ and $35 \mathrm{kDa}$ in chilli leaves (Figure 5). Upon treatment with Burkholderia sp. strain TNAU1 a chitinase with an apparent molecular weight of $28 \mathrm{kDa}$ was induced three days after treatment. The level of the 28 $\mathrm{kDa}$ chitinase decreased thereafter.

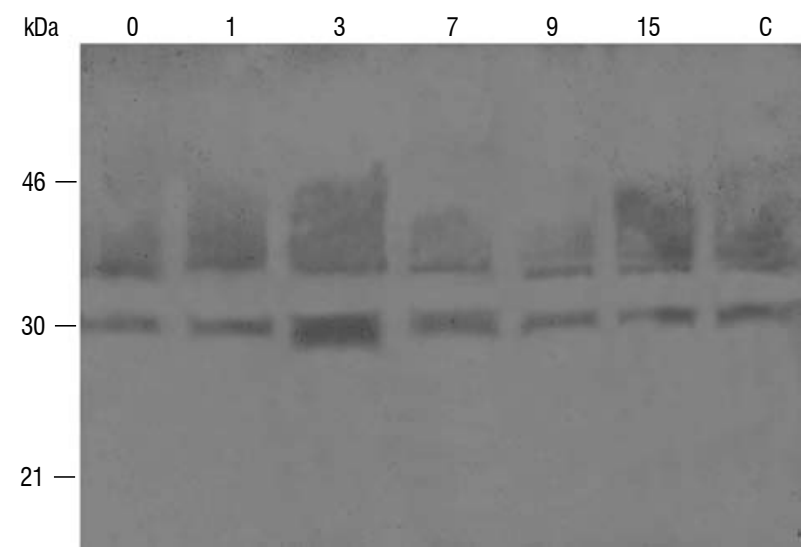

Figure 5. Induction of chitinase in chilli leaves in response to treatment with Burkholderia sp. strain TNAU-1. Aliquots of total proteins $(100 \mu \mathrm{g})$ extracted from control (lane $\mathrm{C}$ ) and Burkholderia sp. strain TNAU-1-treated chilli leaves were analyzed by Western blotting after SDS-PAGE using barley chitinase antiserum. The numbers indicate days after treatment. Molecular weight markers are shown on the left.

\section{DISCUSSION}

Plants possess various biochemical defense mechanisms to protect themselves from pathogenic microorganisms and many of the defense reactions are due to the activation of defense-related genes. The level of accumulation of defense chemicals or the rapidity of the induction of defense genes in a host plant is correlated with the degree of its disease resistance (Lawrence et al., 1996). Activation of the plant's own defense system with the aid of biotic and abiotic inducer is a novel technology in the management of plant diseases. Several plant growth-promoting rhizobacteria (PGPR) are known to induce systemic resistance in plants against fungal (Van Peer et al., 1991; Wei et al., 1991; Thangavelu et al., 2003; Yan et al., 2002), bacterial (Vidhyasekaran et al., 2001) and viral pathogens (Raupach et al., 1996; Murphy et al., 2000). Induced resistance in plants by application of PGPR is often associated with increased activity of peroxidase, lignin deposition, increase in phenolic content and induction of pathogenesis-related (PR)-proteins (Ramamoorthy et al., 2001). Verhagen et al. (2004) reported a substantial change in the expression of 97 genes out of more than 8,000 genes surveyed in the roots of Arabidopsis in response to treatment with ISR-inducing bacterium $P$. fluorescens WCS417r by using microarray analysis. In the present study the biochemical alterations in chilli plants in response to treatment with Burkholderia sp. strain TNAU-1 were investigated.

Many phenolic compounds are known to be antimicrobial, function as precursors to structural polymers such as lignin, or serve as signal molecules to activate plant defense genes (Dakora, 1996). Increase in phenolic content in plants has been correlated with increased resistance to pathogens (Velazhahan and Vidhyasekaran, 1994). Singh et al. (2003) demonstrated that foliar application of Pseudomonas fluorescens strain Pf4 and $P$. aeruginosa strain Pag enhanced the phenolic acids viz., gallic, chlorogenic and cinnamic acids content as well as total phenolics within $24 \mathrm{~h}$ after application in chickpea. In the present study chilli leaves when sprayed with powder formulation of Burkholderia sp. strain TNAU-1 showed dramatic increase in phenolic content one day after treatment and the maximum accumulation of phenols was observed seven days after treatment with Burkholderia sp. strain TNAU-1 The phenolic content subsequently declined but remained significantly at higher levels when compared with control at all sampling stages. The increase in phenolic 
content in chilli in response to treatment with Burkholderia sp. strain TNAU-1 in the present study might have contributed to increased physical and mechanical strength of host cell wall and thereby increased resistance to $C$. capsici.

Peroxidases are involved in the lignification, suberification, polymerization of hydroxy proline rich glycoproteins, regulation of cell wall elongation, wound healing and plant defense (Yoshida et al., 2003). Furthermore, peroxidase itself was found to inhibit spore germination and mycelial growth of Pseudocercospora abelmoschi and $P$. cruenta (Joseph et al., 1998). Caruso et al. (2001) demonstrated that a basic hemeperoxidase (WP1) with a molecular mass of $36 \mathrm{kDa}$ purified from wheat kernels inhibited germ tube elongation of Fusarium culmorum, Trichoderma viride and Botrytis cinerea. Zdor and Anderson (1992) observed an increase of peroxidase activity as well as an increase in the level of mRNAs encoding for PAL and chalcone synthase in the early stages of interaction between bean roots and various bacterial endophytes. The results of the present study indicate that three new peroxidase isozymes (P0-1, P0-2 and P0-3) were induced in chilli leaves upon treatment with Burkholderia sp. strain TNAU-1. The activity of all the peroxidases was at the maximum level three days after treatment and subsequently decreased. The activity of PO was very low or at undetectable level in control leaves. The occurrence of new PO isoforms is suggestive of their synthesis de novo as a result of Burkholderia sp. strain TNAU-1 treatment. The increased PO in chilli leaves treated with Burkholderia sp. strain TNAU-1 might be involved in lignin biosynthesis which in turn might have contributed to disease resistance.

Many phenols and their oxidation products such as quinones are highly toxic to the invading fungi (Sequeira, 1983). Both PO and PPO catalyze the oxidation of phenolic compounds through a PPO-PO- $\mathrm{H}_{2} \mathrm{O}_{2}$ system (Srivastava, 1987). Polyphenol oxidases (PPO) are copper containing enzyme and involved in catalyzing the oxygen-dependent oxidation of phenols to quinones ( $\mathrm{Li}$ and Steffens, 2002; Vaughn and Duke, 2006). A number of studies have correlated the induction of PPO activity with a resistance response (Srivastava, 1987; Velazhahan and Vidhyasekaran, 1994; Thipyapong et al., 2007; Jung et al., 2011). Li and Steffens (2002) demonstrated that overexpression of PPO in transgenic tomato plants resulted in enhanced resistance to the bacterial pathogen Pseudomonas syringae pv. tomato. Thipyapong et al. (2004) demonstrated that antisense down regulation of PPO in tomato results in enhanced susceptibility to Pseudomonas syringae pv. tomato. The results of the present study indicate that protein extracts obtained from Burkholderia sp. strain TNAU-1 treated plants exhibited a major polyphenol oxidase (PPO-1) one day after treatment. The activity of PP0-1 subsequently decreased, but continuously present throughout the experimental period of 15 days. The activity of PPO was very low or at undetectable level in control leaves. The induced PPO might have involved in the resistance of chilli against $C$. capsici through oxidation of phenolic compounds to fungitoxic quinones.

Accumulation of pathogenesis-related (PR) proteins is known to be associated with systemic acquired resistance (SAR) in plants (Ryals etal., 1996). Several studies have shown that PR-proteins are also induced in plants upon treatment with P. fluorescens (Hynes and Lazarovits, 1989; Maurhofer et al., 1994; M'Piga et al., 1997). PR-proteins like chitinase and $\beta-1,3$-glucanase have the potential to hydrolyze chitin and $\beta-1,3$-glucan respectively, which are major components of fungal cell walls. Moreover the chitinase and glucanase release elicitors from the walls of fungi which, in turn, stimulate various defense responses in plants (Ham et al., 1991; Ren and West, 1992). Maurhofer et al. (1994) reported that PR-proteins viz., PR-1a, 1b, 1c, endochitinase and $\beta-1,3-$ glucanases were induced in the intercellular fluid of tobacco leaves of plants grown in the presence of $P$. fluorescens strain CHAO. Using cytochemical labelling of chitin, M'Piga et al. (1997) demonstrated disorganization of Fusarium oxysporum f. sp. radicis-lycopersici hyphae colonizing bacterized tomato roots due to chitin degradation suggesting accumulation of chitinolytic enzymes in bacterized plants. The PR-5 family comprises proteins displaying a certain degree of homology over their amino acid sequences to thaumatin-like protein, a sweet tasting protein isolated from the fruits of the West African shrub Thaumatococcus danielli (for review, see Velazhahan et al., 1999). TLPs have been shown to have antifungal activity against a broad spectrum of fungal pathogens (Velazhahan et al., 1999).

Furthermore, it has been demonstrated that overexpression of chitinase and TLP in transgenic crop plants was associated with enhanced resistance to different fungal pathogens (Datta and Muthukrishnan, 1999). Immunoblot analysis of protein extracts from Burkholderia sp. strain 
TNAU-1 treated plants in the present study revealed that a chitinase with an apparent molecular weight of $28 \mathrm{kDa}$ was induced three days after treatment. Western blot analysis for TLP revealed that two proteins with sizes of 23 and $25 \mathrm{kDa}$ cross reacting with grapes TLP antibody were induced three days after treatment. These results indicated that chitinase and TLPs are present at low or undetectable levels in control plants and are inducible after foliar application of Burkholderia sp. strain TNAU-1 Hence, it is also possible that increased resistance in chilli due to foliar application of Burkholderia sp. strain TNAU-1might be related to the accumulation of PRproteins in addition to accumulation of phenolics.

The coordinate expression of many different defense mechanisms in induced plants suggests that these defense responses may be involved in restricting the development of $C$. capsici. In recent years, many antifungal protein genes have been utilized to transform crop plants in an attempt to increase resistance to diseases (Collinge et al., 2010). However, it is suggested that the constitutive expression of defense genes may likely impose a considerable drain on energy and metabolic resources whereas inducible defenses would impose a significantly lower metabolic cost (Herms and Mattson, 1992; Heil and Bostock, 2002). Hence induction of systemic resistance in chilli when required by application of Burkholderia sp. strain TNAU-1 offers new prospects for ecofriendly management of chilli anthracnose disease.

\section{REFERENCES}

Afroz A, Ali GM, Mir A, Komatsu S (2011) Application of proteomics to investigate stress-induced proteins for improvement in crop protection. Plant Cell Rep. 30: 745-763.

Anand T, Raguchander T, Karthikeyan G, Gopalakrishnan C, Bhaskaran R, Ganeshamoorthi P (2007) Induction of systemic resistance by plant growth promoting rhizobacteria in chilli plants against fruit rot disease. World J. Agrl. Sci. 3(6): 815-824.

Bosland PW, Votava EJ (2003) Peppers: vegetable and spice capsicums. CAB International, England, pp. 233.

Bradford MM (1976) A rapid and sensitive method for quantification of microgram quantities of protein utilizing the principle of protein-dye binding. Anal. Biochem. 72: 248-254.

Collinge DB, Jorgensen HJL, Lund OS, Lyngkjaer MF (2010) Engineering pathogen resistance in crop plants: current trends and future prospects. Annu. Rev. Phytopathol. 48: 269-291.

Caruso C, Chilosi G, Leonardi L, Bertini L, Magro P, Buonocore V, Caporale $C$ (2001). A basic peroxidase from wheat kernel with antifungal activity. Phytochem. 58: 743-750.

Dakora FD (1996) Diverse functions of isoflavonoids in legumes transcend anti-microbial definitions of phytoalexin. Physiol. Mol. Plant. Pathol. 49: 1-20.
Datta SK, Muthukrishnan S (1999) Pathogenesis-Related Proteins in Plants. Boca Raton, FL: CRC Press. pp. 288.

Eshel D, Beno-Moualem D, Lorang JM, Dinoor A, Prusky D (2002) Induction of peroxidase during infection of unripe persimmon fruit by Alternaria alternata: a possible Quiescence mechanism. J. Phytopathol. 150: 357-362.

Hadden JF, Black LL (1989) Anthracnose of pepper caused by Colletotrichum spp. Proceeding of the International Symposium on Integrated Management Practices: Tomato and Pepper Production in the Tropics. Asian Vegetable Research and Development Centre, Taiwan, pp.189-199.

Ham K, Kauffmann SS, Albersheim P, Darvill AG (1991) Host-pathogen interactions. XXXIX. A soybean pathogenesis-related protein with $\beta-1,3$ glucanase activity releases phytoalexin elicitor-active heat-stable fragments from fungal cell walls. Mol. PI. Microbe Interact. 4: 545-552.

Heil M, Bostock RM (2002) Induced systemic resistance (ISR) against pathogens in the context of induced plant defences. Ann. Bot. 89: 503-512.

Herms DA, Mattson WJ (1992) The dilema of plants: to grow of defend. Quarterly Rev. Biol. 67: 283-335.

Hynes RK, Lazarovits G (1989) Effect of seed treatment with plant growth promoting rhizobacteria on the protein profiles of intercellular fluids from bean and tomato leaves. Can. J. PI. Path. 11: 191-197.

Jayaraman KS, Ramunja MN, Vijayaraghavan PK, Vaidhyanathan CS (1987) Studies on the purification of banana polyphenol oxidase. Food Chem. 24 203-217.

Joseph LM, Tan TK, Wong SM (1998) Antifungal effects of hydrogen peroxide and peroxidase on spore germination and mycelial growth of Pseudocercospora species. Can. J. Bot. 76: 2119-2124.

Jung WJ, Park RD, Mabood F, Souleimanov AL. Smith D (2011) Effects of Pseudomonas aureofaciens 63-28 on defense responses in soybean plants infected by Rhizoctonia solani. J. Microbiol Biotechnol. 21: 379-386.

Laemmli UK (1970) Cleavage of structural proteins during the assembly of the head of bacteriophage T4. Nat. 227: 680-685.

Lawrence CB, Joosten MHAJ, Tuzun S (1996) Differential induction of pathogenesis-related proteins in tomato by Alternaria solani and the association of a basic chitinase isozyme with resistnace. Physiol. Mol. Plant Pathol. 48: 361-377.

Li L, Steffens JC (2002) Overexpression of polyphenol oxidase in transgenic tomato plants results in enhanced bacterial disease resistance. Planta. 215 239-247.

M'Piga P, Belanger RR, Paulitz TC, Benhamou N (1997) Increased resistance to Fusarium oxysporum $\mathrm{f}$. $\mathrm{sp}$. radicis-lycopersici in tomato plants treated with the endophytic bacterium Pseudomonas fluorescens strain 63-28. Physiol. Mol. PI. Pathol. 50: 301-320.

Madhavan S, Paranidharan V, Velazhahan R (2010) RAPD and virulence analyses of Colletotrichum capsici isolates from chilli (Capsicum annuum). J. Plant Dis. Protect. 117(6): 253-257

Maurhofer M, Hase C, Meuwly P, Metraux JP, Defago G (1994) Induction of systemic resistance of tobacco to tobacco necrosis virus by the rootcolonizing Pseudomonas fluorescens strain CHAO: Influence of the gacA gene and of pyoverdine production. Phytopathology. 84: 139-146.

Mistry DS, Sharma IP, Patel ST (2008) Biochemical parameters of chilli fruits as influenced by Colletotrichum capsici (Sydow) Butler and Bisby infection. Karnataka J. Agrl. Sci. 21: 586-587.

Murphy JF, Zehnder GW, Schuster DJ, Sikora EJ, Polston JE, Kloepper JW (2000) Plant growth-promoting rhizobacterial mediated protection in tomato against tomato mottle virus. Plant Dis. 84: 779-784.

Ramamoorthy V, Vishwanathan R, Raghuchander T, Prakasam V, Samiyappan $\mathrm{R}$ (2001) Induction of systemic resistance by plant growth promoting rhizobacteria crop plants against pets and disease. Crop Protect. 20:1-11.

Raupach GS, Liu L, Murphy JF,Tuzun S, Kloepper JW (1996) Induced systemic resistance in cucumber and tomato against cucumber mosaic cucumovirus using plant growth-promoting rhizobacteria (PGPR). Plant Dis. 80: 891-894. 
Ren YY, West CA (1992) Elicitation of diterpene biosynthesis in rice (Oryza sativa L.) by chitin. Plant Physiol. 99: 1169-1178.

Roth U, Friebe A, Schnabl H (2000) Resistance induction in plants by a brassinosteroid-containing extracts of Lychnis viscaria L.. Zeit. Naturforsch. 55c: 1-25.

Ryals JA, Neuenschwander UH, Willits MG, Molina A, Steiner HY, Hunt MD (1996) Systemic acquired resistance. Plant Cell. 8: 1809-1819.

Sequeira $L$ (1983) Mechanisms of induced resistance in plants. Annu. Rev. Microbiol. 37: 51-79.

Singh UP, Sarma BK, Singh DP (2003) Effect of plant growth-promoting rhizobacteria and culture filtrate of Sclerotium rolfsii on phenolic and salicylic acid contents in chickpea (Cicer arietinum). Current Microbiol. 46: 131-140.

Srivastava SK (1987) Peroxidase and polyphenol oxidase in Brassica juncea injected with Macrophomina phaseolina (Tassio) and their implications in disease resistance. J. Phytopathol. 120: 249-254.

Swain T, Hillis WE (1959) The phenolic constituents of Prunus domestica. I. The quantitative analysis of phenolic constitutents. J. Sci. Food Agric. 10: 63-68

Than PP, Prihastuti H, Phoulivong S, Taylor PWJ, Hyde D (2008a) Chilli anthracnose disease caused by Colletotrichum species. J. Zhejiang Univ. Sci. 9: 764-778.

Than PP, Jeewon R, Hyde KD, Pongsupasamit S, Mongkolporn 0, Taylor PWJ (2008b) Characterization and pathogenicity of Colletotrichum species associated with anthracnose disease on chilli (Capsicum spp.) in Thailand. Plant Pathol. 57: 562-572.

Thangavelu R, Palaniswami A, Doraiswamy S, Velazhahan R (2003) The effect of Pseudomonas fluorescens and Fusarium oxysporum f.sp. cubense on induction of defense enzymes and phenolics in banana. Biol. Plant. 46: 107-112.

Thipyapong P, Hunt MD, Steffens JC (2004) Antisense downregulation of polyphenol oxidase results in enhanced disease susceptibility. Planta. 220: 105-117.

Thipyapong P, Stout MJ, Attajarusit, J (2007) Functional analysis of polyphenol oxidases by antisense/sense technology. Molecules 12: 1569-1595.

Van Loon LC, Bakker PAHM, Pieterse CMJ. 1998. Systemic resistance induced by rhizosphere bacteria. Annu. Rev. Phytopathol. 36: 453-483.

Van Loon LC (2007) Plant responses to plant growth-promoting rhizobacteria. Eur. J. Plant Pathol. 119: 243- 254
Van Peer RG, Neimann J, Schippers B (1991) Induced resistance and phytoalexin accumulation in biological control of Fusarium wilt of carnation by Pseudomonas sp. strain WCS417r. Phytopathology. 81:728-734.

Vaughn KV, Duke SO (2006) Function of polyphenol oxidase in higher plants. Physiol. Plant. 60: 106-112.

Velazhahan R, Datta SK, Muthukrishnan S (1999) The PR-5 Family: Thaumatin-Like Proteins. In 'Pathogenesis-related proteins in plants'. (eds. S. K. Datta and S. Muthukrishnan ). CRC Press, Florida, USA. pp. 107-129.

Velazhahan R, Vidhyasekaran P (1994) Role of phenolic compounds, peroxidase and polyphenoloxidase in resistance of groundnut to rust. Acta. Phytopath. Entomol. Hung. 29: 23-29.

Velazhahan R, Cole KC, Anuratha S, Muthukrishnan S (1998) Induction of thaumatin-like proteins (TLPS) in Rhizoctonia solani- infected rice and characterization of two new cDNA clones. Physiol. Plant. 102: 21-28.

Verhagen BWM, Glazebrook J, Zhu T, Chang HS, van Loon LC, Pieterse CM (2004) The transcriptome of rhizobacteria induced systemic resistance in Arabidopsis. Mol. Plant-Microbe Interact. 17: 895-908.

Vidhyasekaran P, Kamala N, Ramanathan A, Rajappan K, Paranidharan V, Velazhahan R (2001) Induction of systemic resistance by Pseudomonas fluorescens Pf1 against Xanthomonas oryzae pv. oryzae in rice leaves. Phytoparasitica. 29: 155-166

Vijayasamundeeswari A, Vijayanandaraj S, Paranidharan V, Samiyappan R, Velazhahan R. (2010) Integrated management of aflatoxin $b_{1}$ contamination of groundnut (Arachis hypogaea L.) with Burkolderia sp. and Zimmu (Allium sativum L. X Allium cepa L.) intercropping. J. Plant Interact. 5: 59-68.

Wei G, Kloepper JW, Tuzun S (1991) Induction of systemic resistance of cucumber to Colletotrichum orbiculare by select strains of plant growth promoting rhizobacteria. Phytopathology. 81: 1508-1512

Yan Z, Reddy MS, Ryu CM, McInroy JA, Wilson M, Kloepper JW (2002) Induced systemic protection against tomato late blight elicited by plant growth-promoting rhizobacteria. Phytopathology. 92: 1329-1333.

Yoshida K, Kaothien P, Matsui T, Kawaoka A, Shinmyo A (2003) Molecular biology and application of plant peroxidase genes. Appl. Microbiol. Biotechnol. 60: $665-670$

Zdor RE, Anderson AJ (1992) Influence of root colonizing bacteria on the defense responses of bean. Plant Soil. 140: 99-107. 